\title{
SCIENCE AND INNOVATION POLICY OF THE RUSSIAN GOVERNMENT: A VARIETY OF INSTRUMENTS WITH UNCERTAIN OUTCOMES?
}

\section{Dezhina Irina G.}

D.Sc. in economics, Head of Research Group on Science and Industrial Policy,

Skolkovo Institute of Science and Technology.

Address: Skolkovo Innovation Center, 3 Nobel Street, Moscow Region, 143026, Russian Federation.

E-mail: i.dezhina@skoltech.ru

\begin{abstract}
This paper explores the state and pace of the development of science and innovation policy in Russia with the goal of finding an explanation for its relatively slow progress. We argue that this slow pace can be explained by three major factors. First, instruments of science and innovation policy are government-centered as manifested in excessive, hands-on government involvement. This is a reflection of the vertically organized Russian innovation system having weak horizontal linkages. Second, the government policy is poorly balanced. While in some areas there is a policy mix, in others, necessary instruments are lacking. This is a result of a growing asymmetry of information under the conditions of weak horizontal linkages. Third, in recent years, changes in economic conditions and international relations started to affect Russia's innovation system. Measures undertaken in response to economic sanctions produced signals that conflict with the science and innovation policy. We illustrate our position by analyzing (1) policy instruments aimed at linking research and commercialization and supporting the improvement of the scientific and technological workforce, and (2) new regulations, which appeared during economic sanctions and are related to the work of foreign science foundations in Russia.

We link our interpretations to theoretical studies of science and innovation policy and a policy mix. The Russian case confirms the theoretical models that describe hierarchical systems in which government dominates and asymmetry of information becomes a persistent problem. Government, as a principal, tries to find new forms of a pursuing agent to implement tasks. In Russia, the lack of monitoring leads to new instruments being added while the existing ones remain uncorrected. As a result, a policy mix becomes more complex and its outcomes are difficult to predict.
\end{abstract}

Keywords: science policy; innovation policy; government; Russia; policy mix; instruments.

Citation: Dezhina, I.G. (2017). Science and Innovation Policy of the Russian Government: A Variety of Instruments with Uncertain Outcomes? Public Administration Issues, Special Issue (electronic edition), pp. 7-26 (in English); doi: 10.17323/1999-5431-2017-0-5-7-26. 
Cience policy is a part of innovation policy while at the same time both policies $\checkmark$ maintain certain autonomy. Science contributes not only to economic growth through technological novelties but also impacts culture, education, and society in a broader context. In turn, innovations may appear not only as a result of scientific research. Here we define science policy as a government policy aimed at the funding, conduct and dissemination of scientific research. Innovation policy is a government policy fostering the use of research and development to produce new and competitive products and processes.

In terms of instruments, science and innovation policy are interconnected. There are of course matters of pure science policy like grant funding of fundamental research or the organization of scientific work. At the same time, the problem of cooperation between scientific organizations, universities and companies is at the intersection of science and innovation policy. In this paper, we concentrate on policy measures introduced in Russia that may be considered as a part of both science and innovation policy. These are instruments fostering knowledge transfer from science to business, and a policy on human resources in research and development (R\&D). We also look at how an external environment, such as economic sanctions, is affecting science and innovation policy in Russia.

The Russian government has been actively pursuing science and innovation policy during the post-Soviet period and has applied a policy mix. Russia, especially in recent years, has demonstrated a moderate success in scientific research, but the state of the country's technological innovations is weak. Science policy measures have produced several visible outcomes, including a growing number of Russian publications in highly cited journals and a larger share of highly cited papers published by Russian researchers without foreign co-authors. Yet, the Russian scientific system remains in a turbulent state. Leaders of research institutions and societies increasingly mention "stagnation" and "failure" while describing the current situation in Russian science, which is vocabulary of the early 90s, a period of severe crisis (Dezhina, 2017). This decadent mood can partly be seen as a reaction to the government drive in its science and innovation policy accompanied by certain ignorance of ongoing problems. The response to this push is growing evidence of professional-ethics/ integrity issues inside the Russian scientific community, including plagiarism in research theses, manipulations of authors' affiliations, and unscrupulous calculations of citations indexes (using a Russian science citation index). Often, these problems develop in response to insufficiently thought-through or poorly implemented science policy measures that lead to a misguided perception of government objectives.

We argue that a slow pace of innovative development in Russia may be explained by several factors. First, instruments of science and innovation policy are governmentcentered in terms of excessive, hands-on government involvement. This is a reflection of a vertically organized Russian innovation system with weak horizontal linkages. Second, government policy is poorly balanced. While in some areas there is a policy mix, in others the necessary instruments are lacking. This is a result of a growing asymmetry of information under the conditions of weak horizontal linkages. Third, in recent years, changing economic conditions and international relations has started to affect the Russian innovation system. Measures undertaken in response to economic sanctions produced signals that conflict with the science and innovation policy. 
The paper is organized as follows. First, we describe theoretical approaches to a study of government science and innovation policy. Second, we analyze the current state of the Russian innovation system using quantitative statistical indicators. Third, we discuss the government policy instruments which are aimed at strengthening the research and commercialization results, developing the horizontal linkages in the system, and improving the quality of the scientific workforce. We consider areas in which the number of instruments is adequate and even excessive, and those in which government policy could be more active. Fourth, we analyze an external context influencing science and innovation policy. Finally, we make conclusions about the state of the government science and innovative policy in Russia.

\section{Theoretical background: science and innovation policy through the lens of the principal-agent theory and policy mix}

A theoretical framework for studying government science and innovation policy is underdeveloped. One of the most noticeable concepts for analysis of relationships between government and other actors in the process of implementing science and innovation policy is the principal-agent theory. The principal-agent literature that explores this concept in application to government science and innovation policy treats government as a principal, who disposes a number of resources without sufficient understanding of the interests of the resources' recipients. Guston (1996) and Van der Meulen (1998) analyzed the relationship between government and science as a principal-agent game. Van der Muelen saw this relationship as misbalanced, wherein "one actor, the principal, transfers resources to other actors, the agents, which they should use to realize the objectives of the principal which the principal himself cannot realize". Agents may have their own interests that may only partially overlap with those of the principal. For a principal, a major problem is the information asymmetry between the principal and agent. Therefore, government as a principal "needs the agent, who accepts ... resources and is willing to further the interests of the principal" (Braun et al, 2003).

Caswill (1998) described two opportunities that give the principal-agent theory as a basis for the analysis of science policy. First, it could enable social science policy-makers to better understand their roles, institutional positions and interests. Second, this approach may be the basis of a new science policy agenda, which helps to explain the structures and operations of resource allocation systems both inside and outside the academic science system.

This theory has been verified through the analysis of particular instruments, such as funding agencies as intermediates between policy-makers and scientists (Braun et al, 2003). Each of the parties has certain options. The Principal may trust or monitor. An Agent may comply or not comply with government policy. Each choice creates an incentive for at least one of the two actors to change the status quo. Theoretical studies search for stabilizing arrangements and factors that make parties cooperate and still maintain their disparate identities.

Another theoretical approach defining the role of the government is a "systems of innovation" concept (classical works on this topic were written by R. Nelson (1993), C. Freeman (1995), and B.A. Lundvall (1992)). It also implies an asym- 
metry of information (Chaminade and Edquist, 2010) and focuses the attention on interactions in an innovation process and networks among major stakeholders (government, companies, universities, financial institutes, etc.). Based on this approach, analysis may reveal areas with a greater degree of uncertainty and risk, in which government should conduct its science and innovation policy. This approach also gives the basis for assumptions that innovation policy is closely connected with educational, economic and other policies (Kuhlmann, 2003). Moreover, according to Martin (2016), there is a growing need for R\&D policies to be integrated with industrial, environment and regional policies. In turn, Weiss (2005) underlines that science and technology policies are interconnected with international affairs and affect each other. He claims that their interconnection is so important that it should be recognized as an independent sub-discipline. He sees science and technology as social processes that respond to a variety of economic, social, cultural and political influences. They operate in politicized contexts and are influenced by international affairs. This influence may be reflected in national priorities and relative budget allocations for different scientific and technological fields, the pace of international migration of scientists, and their freedom to communicate and attend meetings outside the country (Skolnikoff, 1993).

These theoretical frameworks underpin umerous empirical studies of government science and innovation policy. For the current study of inter-relations between science and innovation policy the concept of a policy mix is especially appropriate. The term "policy mix" was transferred to science and innovation policy vocabulary in the 2000s. It implies a focus on the interaction and interdependence between different policies as they affect the extent to which independent policy outcomes are achieved. Even though the term emerged in the literature of the 60s, its meaning remains ambiguous (Flanagan et al, 2011). Borrás and Edquist (2013) give the following definition of policy mix: "the specific combination of innovation-related policy instruments which interact explicitly or implicitly in influencing innovation intensities". They underline that there is no ideal combination of policy instruments that would fit all purposes. Moreover, each country has its unique science and innovation policy and therefore the approach 'one-size-fits-all" is irrelevant.

Martin (2016) points out that there are many studies of individual policy instruments but scarce data exist on the analysis of policy mix with regard to science policy. The same is true for innovation policy: according to Witt (2003), innovation policy studies have tended to focus on the analysis of individual policy instruments, or on easily understood combinations of non-interacting instruments. In addition, formal or informal mechanisms for evaluating and governing the wider policy mix affecting innovation are largely absent (Flanagan et al, 2011).

Borrás and Edquist (2013) suggest the classification of policy mix regarding innovation policy. According to them, government may use three types of instruments: regulatory, financial and soft. Regulatory instruments include, for example, competition regulations, intellectual property rights laws, etc. Financial instruments are usually at the center of innovation policy (block support of research, competitive research funding, and tax exemptions). Finally, soft instruments include standardization, public-private partnerships and voluntary agreements. Soft instruments, such as public-private partnerships are increasingly used in innovation policy. 
Borrás (2009) and Flanagan et al (2011) characterize the evolution of a policy mix as both "widening" - the introduction of new and more sophisticated policy instruments - and "deepening" - an expansion of the realm of action for innovation policy. An interesting observation from Flanagan et al (2010) is that it is easier to create new mechanisms than to remove those that have become institutionalized (p. 25). This means that new instruments may conflict with previous ones and, perhaps, old instruments should be corrected before adding new ones.

Another important factor in the analysis of a policy mix is path-dependency. New policy schemes may reproduce existing institutions as possible and rational. Thus, based on the example of the Soviet Union, Chulkov (2014) shows that in centralized economies there is strong information asymmetry between the principal and the agent since the principal cannot identify the true productivity level of the agent.

A policy mix in Russian science and innovation policy has been studied mainly by Russian scholars and there are few systemic works on this subject. Notable large studies include Ivanova, Egorov, Radosevic (2008), who conducted an analysis of the Russian innovation policy mix based on methodology used in the European Union. An analysis by Gokhberg et al (2011) was focused on a science policy mix during the economic crisis of 2008. Dezhina (2008) analyzed the pace of development of science and innovation policy instruments in the post-Soviet period, pointing out a high level of centralization in decision-making and the practice of adopting foreign policy measures, which is unlikely to succeed. Ivanova et al (2012) focused on priority setting in science and innovation policy and comparisons with developed innovative countries. These studies show that while Russia has a large palette of instruments, altogether they do not ensure innovative development even though several successful cases are in place. A major impediment is the disconnection of major actors at a horizontal level.

\section{$\mathrm{R} \& \mathrm{D}$ and innovation activity in Russia}

The most common indicator reflecting the state of science and technology is expenditures on R\&D as a percentage of gross domestic product (GDP). For Russia, this indicator is just over 1\%, compared to $2.03 \%$ in 1990 (TSISN, 1997), before the breakup of the Soviet Union. Currently, these expenditures exhibit a negative dynamic, decreasing from $1.19 \%$ in 2014 to $1.13 \%$ in 2015; budget cuts that started in 2014 are likely to continue this unfortunate trend. In technologically developed countries, the expenditures on $\mathrm{R} \& \mathrm{D}$ vary from $4.29 \%$ (Korea) to $1.7 \%$ (UK) (HSE, 2017b) ${ }^{1}$.

However, the volume of funding per se does not appear to be the only problem. Russia is distinct in another feature - a very low level of business enterprise expenditures on R\&D (BERD). The government budget allocations represent about $70 \%$ of the total expenditures on $\mathrm{R} \& \mathrm{D}$, whereas in developed countries, the partitioning of government and BERD shares is almost the opposite. Overall, BERD in Russia keep diminishing over time (picture 1).

1 Data are for 2015 or latest year available. 
Picture 1

\section{Business Enterprise Expenditures on R\&D in Russia (\% of total expenditures on $R \& D$ )}

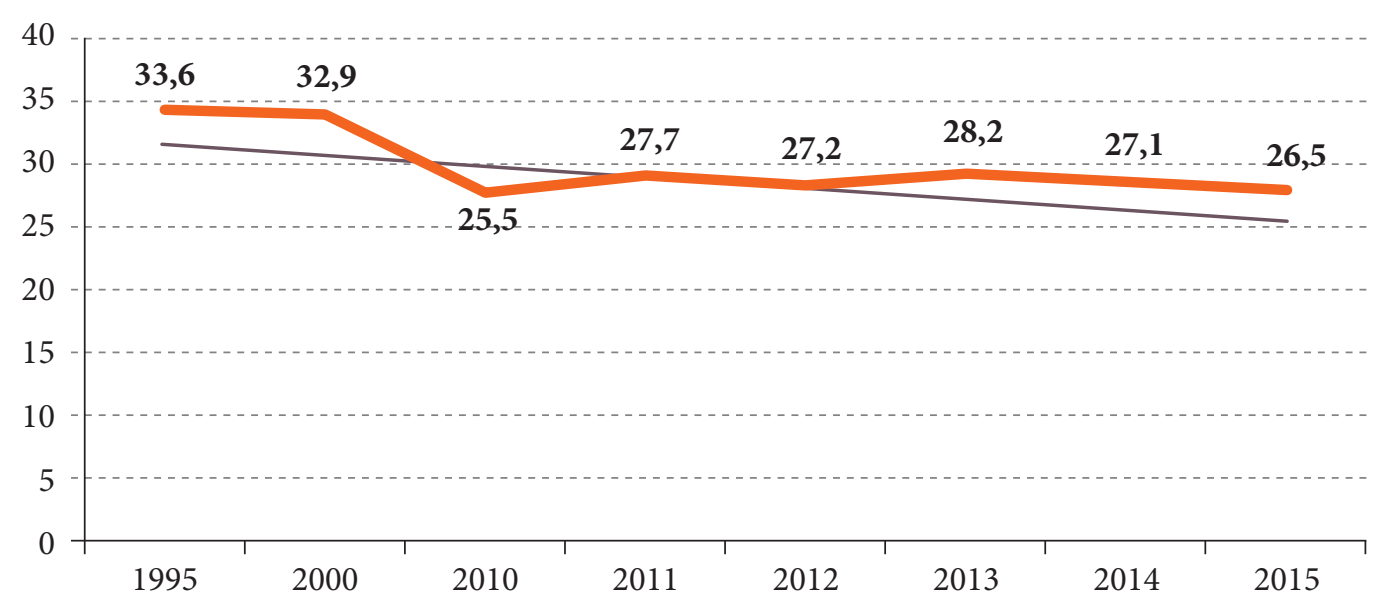

Sources: (HSE, 2016); (HSE, 2017b).

Moreover, "pure" BERD are even lower - the combined direct and indirect government support for business R\&D in Russia is 62\%, compared to $27 \%$ in France, $15 \%$ in USA, and $4 \%$ in Germany (Picture 2). These data indicate that the Russian science and innovation activities area is highly dependent on federal funding and even in the private sector $\mathrm{R} \& \mathrm{D}$ for technological innovations are mostly government-supported.

Picture 2

\section{Government Support for R\&D in the Business Sector, 2014 or latest year available (\% to the total BERD)}

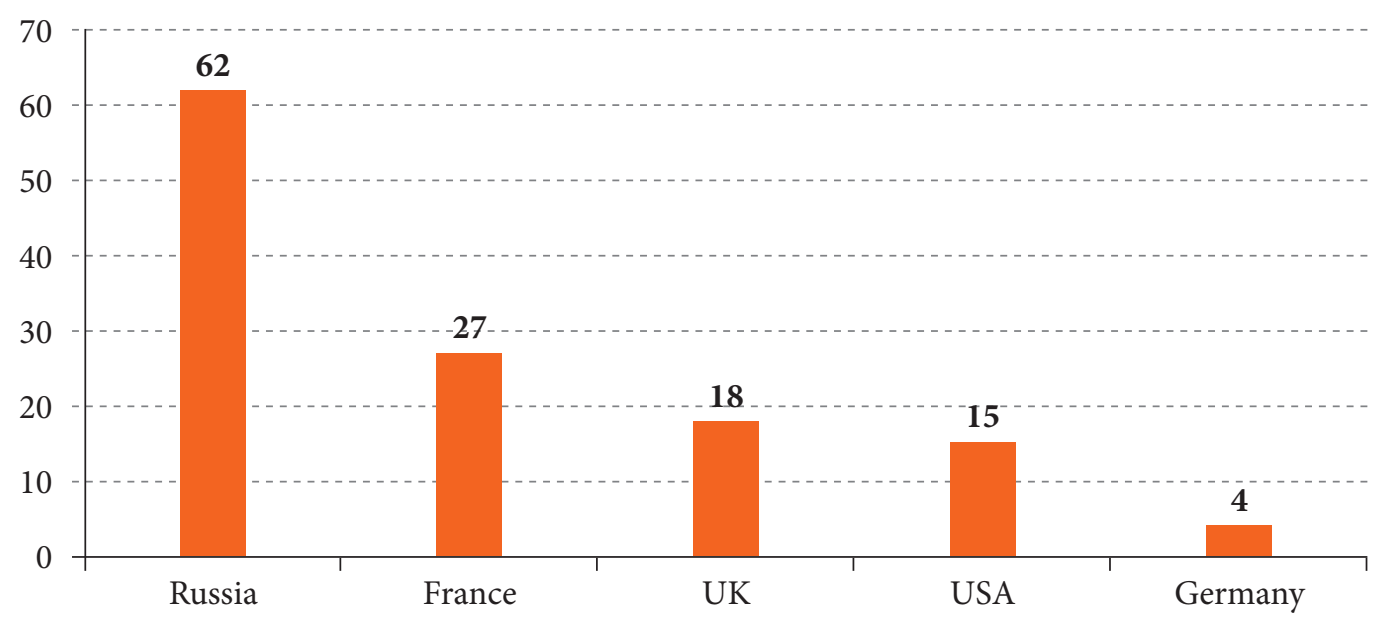

Source: (OECD, 2016). 
These data reveal a heavy reliance of the system on the federal budget. One of its outcomes is the phenomenon of "budget innovators", when the substitution of private funding by public financing is occurring.

Meanwhile the government funding of $\mathrm{R} \& \mathrm{D}$ in Russia is rather modest in absolute terms, being insufficient for effectively boosting innovations. The proportion of innovative enterprises conducting technological innovations remains small - just over $8 \%$ of all enterprises. This contrasts with the situation in technologically developed countries where the share of innovative companies varies from $52.9 \%$ (Belgium) to $26.4 \%$ (Israel) (HSE, 2017a) ${ }^{2}$.

Companies prefer to purchase new technologies (typically, abroad) rather than develop their own. This leads to the country having a technological dependence. Overall, Russia is mostly dependent on high-tech imports, exporting only some "niche" products. The volume of exports is modest - US $\$ 1.65$ billion versus US $\$ 45.6$ billion in UK or US $\$ 71.4$ billion in Germany (HSE, 2017b). The country is least dependent on the import of nuclear technologies (in this area export is higher than import), and most dependent on the import of medical equipment (imports from countries that introduced sanctions is 92\%), pharmaceuticals (over 90\%), machinery and equipment (60\%) (Gnidchenko et al, 2016). The technological dependence is also confirmed by patent statistics. The number of patent applications in Russia is a factor of 20.5 lower than in China, 14 in the U.S., and 1.5 in Germany (HSE, 2017b) ${ }^{3}$.

The latest (2016-2017) World Economic Forum Global Competitiveness Report shows that the Russian innovation system persistently suffers from low levels of industrial spending on $\mathrm{R} \& \mathrm{D}$, government procurement of advanced technological products, and weak university-industry collaboration in $\mathrm{R} \& \mathrm{D}$ (Table 1).

Table 1

Major difficulties in promoting innovation in Russia (score 1-7 (best))

\begin{tabular}{|l|c|c|}
\hline \multirow{2}{*}{\multicolumn{1}{|c|}{ Indicator }} & \multicolumn{2}{c|}{ Score } \\
\cline { 2 - 3 } & $2015-2016$ & $2016-2017$ \\
\hline Company spending on R\&D & 3.2 & 3.3 \\
\hline Government procurement of advanced tech products & 3.3 & 3.3 \\
\hline University-industry collaboration in R\&D & 3.6 & 3.7 \\
\hline Capacity for innovation & 3.8 & 4.0 \\
\hline Quality of scientific research institutions & 4.0 & 4.2 \\
\hline Availability of scientists and engineers & 4.1 & 4.1 \\
\hline
\end{tabular}

Sources: (World Economic Forum Global Competitiveness Report, 2016); (World Economic Forum Global Competitiveness Report, 2017).

2 Data are for 2015 or latest year available.

3 Data are for 2015. 


\section{Government measures to link science and industry}

The focus of Russian science and innovation policy related to encouraging transfer of knowledge kept changing abruptly during the post-Soviet period. In the early 1990s, during a severe economic crisis, the government concentrated on "preserving" science and creating technical infrastructure, such as technology parks and incubators. The assumption behind this activity was that the availability of technical infrastructure would boost the commercialization of research results and increase the economic demand for science.

From the mid-2000s, the emphasis shifted to the establishment of various funding institutions aimed at supporting technological innovations. The first Government Fund supporting R\&D at small innovative enterprises was created in 1994; in the mid-2000s, several new "institutes for development" were established. These are government-funded organizations with a different agenda focused on technological innovations. Examples are the Russian Venture Company (established in 2006), RUSNANO (initially it was a State Corporation established in 2007 with the goal to develop "nanotechnology industry" in Russia), the Russian Fund for Technological Development (reconfigured at the end of the 2000s, with an agenda to provide low interest loans to companies for R\&D and technology development). The assumption was that a combination of financial and infrastructural support would ensure that all stages of innovative development - from idea to new technology or product - would be covered by targeted government support. This ideology received the unofficial name "innovation lift", with an envisioned image of development that moves through the stages just like in a lift, from stage one, where an idea is born, to the last stage production and sales.

Despite the creation of almost every element of an innovative infrastructure, the system was stumbling and R\&D remained loosely connected to technological innovations. The gap between the research and commercial applications became evident. At the beginning of the 2010s, the government realized that horizontal linkages in the innovation system were missing and readjusted its focus to mechanisms for stimulating and strengthening the cooperation between universities and industry. Among the most significant measures introduced in 2010 were technology platforms, programs for innovative development of large state companies, and matching grants for industry-university research cooperation.

Technology platforms represent a non-financial tool for connecting major actors of an innovation system (industry, research institutes, universities) with the overall goal of developing commercially viable technologies. These platforms create a so-called "communication ground" by helping all the parties involved to identify and negotiate promising joint projects. The idea of technology platforms has been adapted from the European Union experience. A total of 35 platforms were established in Russia of which, by 2017 , only about $20 \%$ were functioning. The major reason for such a modest outcome has been the inability of these platforms to connect different stakeholders and the orientation towards federal support and federal technological priorities (Zudin, Kuzyk, Simachev, 2017), thus reducing the interest of private companies to cooperate (Dezhina, 2014a). 
Another new-to-Russia instrument for promoting links between industry and universities was in the form of subsidies distributed competitively to industrial enterprises to fund complex high-tech projects performed together with universities (Government Resolution, 2010). This was the first policy mechanism conceptually close to matching the grants used by governments in many other countries to support corporate research and development. The impact of this instrument was assessed in 2012-2013 using a number of face-to-face interviews with the university and company project leaders. The assessment showed that these companies and universities are in a positive conflict while working together. Some of this friction was related to the typical differences in mentalities and values for businessmen and scientists. These issues, however, have not led to the termination of projects (Dezhina, Simachev, 2013) and mutual understanding improved as the projects kept progressing. The survey revealed the following positive effects of the matching grants:

- increased commitment of university research teams towards solving the scientific and technological problems of companies, and strengthened motivation of university researchers to cooperate, especially among younger scientists;

- improvement of student training due to their involvement in research projects;

- modernization of educational programs in line with industrial needs;

- expansion of research cooperation, formation of consortia that included a company and several universities.

Still, this program, even while being one of the most effective, has a low disseminating potential. This is again government funding spent on $\mathrm{R} \& \mathrm{D}$ in companies' interests. When stimuli for competition are low, this incentive may also lead to the substitution of private money by public funding.

A separate measure was directed towards large state corporations with the goal of making them more innovative. A special program called the "Program for innovative development of large state companies" was initiated in 2010. The government was using this program to "push" companies towards innovations. The companies participating in this program had to set out their plans for innovative development, increase R\&D expenditures, and improve their technological base. After 4 years of functioning, the first evaluation of this program was conducted (Gershman et al, 2015). It demonstrated that the majority of companies preferred incremental innovations, with $69 \%$ of them having conducted $R \& D$ that could be regarded as original only within that company, and only $34 \%$ stated that they had undertaken R\&D novel for the world market. Overall companies were oriented toward state procurement. Officials now admit that the program itself and attempts to restructure it did not yield promising results because the political impulse became less oppressive when economic situation in the country had worsened (Medovnikov, 2017). As the companies were forced to cooperate with universities, without having a genuine need for doing so, the cooperation in many ways turned out to be too formal, and did not sufficiently strengthen the industry-university linkages.

The most recent policy trend is "picking winners" in the form of support to medium-size technological companies that may give a boost to the entire in- 
novation system, thus making Russia more visible internationally. The pace of development of such companies is rather impressive. Some of them have $20 \%$ annual gains growth. In order to help these companies to grow even faster and turn into trans-national companies, the government started, in 2016, a pilot program called "Support of private high-tech companies-leaders till 2020" ("National Champions"). It is modeled, as are many other Russian initiatives, on the foreign experience. The approach is to provide individual support to companies (mostly in nonmonetary forms, such as informational support and consulting; simplifying export procedures and such) (HSE, PWC, Fund for Industrial Development, 2016).

In 2016, a survey of 155 fast-growing medium-size technological companies was conducted to analyze intensity, directions, forms, problems and prospects of their cooperation with higher education institutions (Dezhina, Medovnikov, Rozmirovich, 2017). It showed that during the previous 5 years, $80 \%$ of the surveyed companies had collaborated with universities on joint R\&D projects. These companies are prepared to invest moderate funds in exploratory research conducted by university specialists (including graduate students) but such contracts are irregular. Overall, "open innovations" are unpopular among these companies, who prefer to implement their own in-house R\&D.

Companies were asked about their preferred policy instruments the government should use to facilitate industry-university cooperation. Almost all of the measures mentioned are financial, with 76\% believing that the government should fund joint R\&D projects. Two other popular instruments are related to the support of personnel or students: 59\% of respondents think that the government should co-fund university graduates recently hired by a company and $56 \%$ believe that the government should support fellowships for students trained by industry. Only $8 \%$ of the surveyed companies consider government support unessential for their plans to interact with universities.

This overview of policy mix shows that the government's push was at the core of most actions, and policy instruments were encouraging all actors to look for budget support. The phenomenon of "budget innovators" became visible from the sides, science and industry alike.

\section{Support of Scientific and Technological Talent}

The quality of the workforce is crucial for the effectiveness of science and innovation activities. It also influences the level of demand for science in the economy and society. After the breakup of the Soviet Union, the number of researchers in the country decreased sharply due to severe budgetary cuts and in the absence of other sources of support. In many cases, these were irreversible losses, the consequences of which are felt to this day. There is a dearth of "middle-aged" Russian scientists (40-60 years old) due to emigration or moves to other economic sectors. Young researchers do not stay in scientific research for long and therefore this "generation gap" does not narrow.

In Russian human resources, policy in science and technology was inconsistent. The Government for years used various policy instruments to temporarily support young researchers (usually defined as younger than 39). Various 
types of grant competitions (including Presidential) exist, both personal and for research teams, but it does not change the situation dramatically. Moreover, recent surveys show that emigration moods among young scientists are increasing. The scientific brain drain from Russia remains an important problem, as these outflows were never counterbalanced with comparable inflows of scientists from abroad. Even young scientists that work in modern labs consider leaving to go abroad because they do not see clear prospects for their career in Russian science (Dushina, Nikolaenko, Evsikova, 2016). Thus, according to the survey conducted in the institutes of the Siberian branch of the Russian Academy of Sciences, about $40 \%$ of young researchers do not see their career prospects in Russia (Aseev, 2016). They also refer to worsening economic conditions for scientific research, such as difficulties in obtaining travel funds to attend international conferences and in importing supplies and equipment, as well as other financial limitations.

The government approach towards attracting and retaining young scientists is based on selective temporary support of scientific projects conducted by young scientists, which is not enough. The young should be looking at prospects of becoming heads of laboratories, getting permanent positions at universities, and other kinds of stability besides short-term grant support. Measures to retain young people in science should be a part of every stage of career development starting from graduate school. Postdoctoral positions are important as an instrument for selecting those who are capable of continuing research careers. A postdoctoral status should be combined with measures to enhance various types of mobility. Then, programs supporting the establishment of new laboratories chaired by young scientists should be widened. At present, only one out of ten young specialists is satisfied with his/her scientific career (Saprykina, 2017).

Instead, the government emphasizes attracting Russian-speaking researchers from abroad. At the end of the first decade of the this century, the Russian government developed initiatives for engineering a "reverse influx" of talent - that is, to attract Russian-speaking scientists from other countries, all with a view to seeing the research diaspora as a potential source capable of better representing Russian science in the global scientific community (Dezhina, 2011). This approach involved, firstly, the creation of a special program attracting members of the Russian scientific diaspora to participate in and/or lead research conducted by Russian universities. Under this program, 160 laboratories have been created with about half of them chaired by the Diaspora scientists. Secondly, the Russian-speaking diaspora was invited to peer-review Russian government projects and programs.

Government attention to Diaspora is practical, on the one hand, and not clearly articulated, on the other. In particular, it is not defined as to which representatives of Diaspora are welcome. As a result, the outcomes are mixed.

Researchers who have the experience of working in Western laboratories brought their expertise in organization and management of research to Russia along with their professional knowledge, which helped to make Russia more visible on an international landscape due to the increased publication record in international peer-reviewed journals. The Russian-speaking diaspora actively promotes scientific cooperation, for example, providing assistance to universities in opening modern labs using federal funds (Russkogovoryashchie uche- 
nye, 2015). The survey conducted in 2015 among 150 representatives of the Russian-speaking academic diaspora has shown that those of its members who actively interact with Russia are politically loyal and focused on furthering cooperation (Dezhina, 2015).

At the same time there is anecdotal evidence of "negative selection" of returnees. Scientists, who did not manage to secure good positions abroad or those who work under temporary appointments, are most active in collaborating with Russia and returning on temporary or permanent positions ${ }^{4}$.

Despite the mixed results of working with Diaspora, the government is considering a new project that could be inspired by the successful Chinese experience: to attract 15000 scientists to the country within 5 years (Vishnevetskaya, 2016). It is not clear what stands behind this number and why exactly so many scientists should come. The question also remains whether they should return temporarily or permanently and what policy instruments will be used to retain them in Russia.

Alongside the external movement of researchers, internal, inter-sectoral mobility - that is, scientists moving from the academy to industry, and vice versa - is also important for both knowledge transfer and for creating the demand for science. Russian intersectoral mobility has two characteristics - first, its level or intensity is extremely low (Elsevier, 2011); and second, Russian researchers tend to move within the government sector - from universities to research institutes and vice versa. An exchange of human resources between companies and universities and/or research institutes is insignificant and is not encouraged by any policy measures. Instead, Russian policy towards internal mobility so far has been focused on the issue of regional diversity. This is a slightly misleading direction because economic factors hamper the geographic mobility of researchers (Moscow and St.-Petersburg where the concentration of the top-level labs is the highest are too expensive to live in.)

In countries with developed scientific complexes, intersectoral mobility is promoted and stimulated primarily through measures aimed at linking universities and business (Dezhina, 2014b) In these countries, there has been a gradual transition from the use of direct measures (for instance, targeted grants) to indirect ones related to the regulation of the consulting and entrepreneurial activities of professors, various types of joint initiatives and, inter alia, training. Support of intersectoral mobility is of vital importance in the system with weak horizontal linkages. It would also improve the quality of the workforce in the longer-term.

\section{External Factors: Sanctions and Economic Conditions}

Economic sanctions, which came in force in 2014, should be separated from domestic economic problems, even though they are interconnected. Economic problems associated with the decline of the ruble also started in 2014 and have led to more expensive imports of scientific equipment and supplies.

\footnotetext{
4 This was one of the findings which resulted from the personal interviews with Russian researchers working abroad, conducted by the author in 2016-2017.
} 
A 'milestone' countdown for the influence of sanctions began with the adoption of the Law on undesirable foreign organisations in May 2015 (Federal Law 129, 2015). Combined with the by then already existing Law on foreign agents (Federal Law 121, 2012), it triggered the destruction of the system of non-governmental support of science through not-for-profit foundations and contributed to overall changes in the academic atmosphere in Russia.

According to the Law on undesirable foreign organisations, recognising an organisation as an undesirable foreign one means a ban on its activities. This status is assigned to organisations whose activity poses a threat to the constitutional order, the defence capability or the security of Russia. Often these are organisations which fund non-governmental organisations (NGOs) that are recognised as undesirable, with the latter subsequently being recognised as "foreign agents" (Peremitin, 2015).

Russian science, which had already had a shortage of non-governmental foundations, has seen the forced exodus of organisations which for many years had supported research and training programmes, both in natural and social sciences. The laws resulted in the closure of several American foundations that supported research and education in Russia - such as the Russian branch of the MacArthur Foundation (Muhametshina, 2015), the U.S. Russia Foundation ${ }^{5}$, IREX, and CRDF Global Moscow office.

The MacArthur Foundation and the U.S. Russia Foundation ended up on the same 'stop-list'. As a result, the management of these organizations took the decision in 2015 to terminate their work in Russia. The MacArthur Foundation had launched its programmes in Russia back in 1992 and supported both individual researchers in social sciences and Russian universities (including, for example, the National Research University "Higher School of Economics"). The U.S. Russia Foundation ran the EURECA Program, aimed at the development of technology commercialization skills in Russian universities and the training of U.S. and Russian students.

In 2016, IREX closed its programs in Russia ${ }^{6}$, followed in 2017 by CRDF Global, known for its very successful joint program with the Ministry of Education and Science conducted in 1998-2013 on the establishment of research and educational centers in Russian universities.

The closure of those foundations was a sound decision by their management, because once an organisation is qualified as a "foreign agent", its day-to-day activities become severely impeded: it becomes virtually impossible to work with public institutions, but it is exactly public institutions that constitute the bulk of research and education organisations in Russia. The same situation applies to "undesirable organisations" - receiving grants from them becomes a risky business.

The reason why the foundations that for so many years have supported education and science, and whose activities have repeatedly been praised by Russian authorities, ended up as undesired foreign agents lies in politics and has nothing to do with their support of science.

\footnotetext{
5 https://en.wikipedia.org/wiki/U.S._Russia_Foundation

${ }^{6}$ http://www.ntv.ru/novosti/1624710/
} 
Then, equipment and reagents, imported mainly from countries that have imposed sanctions, became increasingly scarce, while their costs spiked because of the decline of the rouble exchange rate. Many foreign companies, including European ones, started to curtail the supply of scientific equipment (Gerden, 2015) and materials, fearing that they could be used for military purposes (e.g. components for lasers).

Some universities and research organisations on their own reacted to the external pressure in a somewhat strange manner by reducing the number of business trips to western countries and by monitoring publications in the foreign scientific press not only to identify those entitled to bonuses for being published in toprated journals. Special departments supervising interactions with foreigners are being resurrected at universities and research institutes (Gerden, 2015).

At the same time, it should be underlined that no formal restrictions on the employment of foreign scientists and engineers have been issued by the federal authorities, and official documents and official speeches continued to be filled with calls for internationalisation. It has been repeatedly emphasised that science "does not have borders", and therefore international scientific cooperation should be the basis for development. Thus, the $5-100^{7}$ Project is aimed at encouraging universities to publish their research papers abroad, participate in international activities and recruit foreign specialists.

Overall, foreign affairs and economic factors turned out to be in conflict with the intentions expressed through science and innovation policy and aimed at the development of international scientific and technological cooperation.

\section{Conclusions}

As theoretical studies show, instruments for science and innovation policy are not universal and vary considerably among countries and therefore the "onesize-fits-all" approach is irrelevant. The Russian case is indeed unique and important for understanding the complexity of these policies in developing economies with strong past-dependency.

The analysis of the current state of science and innovation policy in Russia shows that despite the high level of government activities and the introduction of a policy mix, the well-functioning innovation system is still absent. The Russian innovation system is mostly government-supported and regulated. This is one reflection of path-dependency. New policy schemes continually reproduce existing institutions. This is one of the reasons why Russia has a slow pace in innovative development. Business enterprise expenditures on R\&D remain stagnant and technological companies are still expecting the government to fund their R\&D activities. Business in Russia is not driven by competition and therefore technological innovations are not at the core of companies' development strategies.

\footnotetext{
7 Project 5-100 aims at increasing the competitiveness of Russian universities at the international level. The goal of 5-100 Project is to maximize the competitive position of a group of leading Russian universities in the global research and education market. (From: http://5top100.ru/).
} 
The Russian case confirms theoretical models regarding the functioning of hierarchical systems, in which government dominates and asymmetry of information becomes a persistent problem. Government as a principal tries to find new forms of pursuing the agent to implement tasks that it considers important and necessary for scientific and technological development. At the same time, the Russian government does not pay enough attention to the evaluation of its science and innovation policy outcomes. Adding new instruments is not accompanied by the correction of existing ones because of the lack of monitoring. As a result, the asymmetry of information is not decreasing. In hierarchical systems, there is an illusion that since everything is under control, decision-making may be situation-based. The demand for such evaluations becomes low and, in the end, the probability of wrong decisions increases.

At the same time, Russia follows a general trend in the development of policy instruments. In Russia, as in developed countries elsewhere, soft instruments, such as public-private partnerships, are increasingly used in innovation policy. In the area of business-university interactions, the government has applied several instruments, both financial and communicational, in order to facilitate the development of horizontal linkages. However, due to the vertically-organized innovation system, in which both companies and universities are seeking federal support, these instruments were ineffective in boosting cooperation. The same is confirmed by the data from medium-size technological companies. These companies believe that the government may help with facilitating university-industry cooperation by using financial instruments aimed at easing the burden of funding joint $\mathrm{R} \& \mathrm{D}$ activities and educational training. In a way, the government stimulated the widening of a phenomenon of "budget innovators" by substituting private funding with public.

Quality of human resources is another direction of science and innovation policy to which the governments pays increasing attention. Improvement of qualitative characteristics of the scientific and technological workforce continues to be a challenge for the Russian government. Measures aimed at supporting young scientists and at cooperation with Diaspora are very reasonable; however, these measures should be complemented by indirect instruments stimulating intersectoral mobility and cooperation with industry.

The sanctions contributed to a complexity of the situation in the Russian innovation system by causing signals that contradict official science and innovation policy. While the latter are promoting international cooperation, the reaction of the government to economic sanctions has led to the termination of foreign foundations' activities in Russia and, more generally, to a reduction in foreign funding for Russian scientific and technological development, and to difficulties with the transfer of best practices. The sanctions and the changes in economic conditions made it more difficult for research institutes and universities to implement their international activities. In a way, science and innovation policies, with their appeal to scientists and engineers to cooperate internationally, turned out to be more advanced than economic policy. 


\section{DOCUMENTS}

1. Federal'nyi zakon No $121-\mathrm{FZ}$ ot 20 iyulya 2012 "O vnesenii izmenenii v otdel'nye zakonodatel'nye akty Rossiiskoi Federatsii v chasti regulirovaniya deyatel'nosti nekommercheskikh organizatsii, vypolnyayushchikh funktsii inostrannogo agenta" [Federal Law of the Russian Federation No. 121-FZ of July 20, 2012 "On Amendments to a Number of Legislative Acts of the Russian Federation in Part that Regulates Activity of Non-Commercial Organizations, Implementing Function of Foreign Agent"]. Available at: http://www.consultant.ru/document/cons_doc_ LAW_132900/ (accessed: 21 May, 2017).

2. Federal'nyi zakon No $129-\mathrm{FZ}$ ot 23 maya 2015 "O vnesenii izmenenii v otdel'nye zakonodatel'nye akty Rossiiskoi Federatsii” [Federal Law of the Russian Federation No. 129-FZ of May 23, 2015 "On Amendments to a Number of Legislative Acts of the Russian Federation.”]. Available at: https://rg.ru/2015/05/26/fz129-dok.html (accessed: 21 May, 2017).

3. Postanovlenie Pravitel'stva Rossiiskoi Federatsii No 218 ot 9 aprelya 2010 "O merakh gosudarstvennoi podderzhki razvitiya kooperatsii rossiiskikh vysshikh uchebnykh zavedenii i organizatsii, realizuyushchikh kompleksnye proekty po sozdaniyu vysokotekhnologichnogo proizvodstva" [Government resolution of the Russian Federation No. 218 from April 9, 2010 "On the Measures of the Public Support of Cooperation through Russian Higher Educational Institutes and Organizations that Realize Complex Projects Aimed at Creation of High-tech Production"]. Available at: http://www.consultant.ru/document/cons_doc_LAW_99318 (accessed: 21 May, 2017).

\section{REFERENCES}

1. Aseev, A. (2016). 40\% molodykh uchenykh Sibirskogo otdeleniya RAN ne vidyat v Rossii dlya sebya nauchnykh perspektiv [40\% of Young Scientists from Siberian Branch of RAS Do Not See in Russia for Themselves Scientific Prospects] RIA Sibir'. Available at: http://www.ras.ru/news/shownews.aspx?id=98087056-e028-4c428c36-5c483eff0b3d\# content (accessed: 21 May 2017).

2. Borrás, S. (2009). The Widening and Deepening of Innovation Policy: What Conditions Provide for Effective Governance? CIRCLE Working Paper 2009/2, Lund: Lund University. 
3. Borrás, S. \& Edquist, C. (2013). The Choice of Innovation Policy Instruments. Technological Forecasting \& Social Change, vol. 80, pp. 1513-1522.

4. Braun, D. \& Guston, D.H. (2003). Principal-agent Theory and Research Policy: An Introduction. Science and Public Policy, vol. 30, no 5, pp. 302-308.

5. Caswill, C. (1998). Social Science Policy: Challenges, Interactions, Principals and Agents. Science and Public Policy, vol. 25, no 5, pp. 286-296.

6. Chaminade, C. \& Edquist, C. (2010). Rationales for Public Policy Intervention in the Innovation Process: A System of Innovation Approach. In: The Theory and Practice of Innovation Policy: An International Research Handbook. Cheltenham (UK) and Northampton, MA (USA): Edward Elgar, pp. 95-114.

7. Chulkov, D. (2014) Innovation in Centralized Organizations: Examining Evidence from Soviet Russia. Journal of Economic Studies, vol. 41, no 1, pp. 123-139.

8. Dezhina, I. (2008) Gosudarstvennoe regulirovanie nauki v Rossii [Government Regulation of Science in Russia]. Moscow: Magistr. (in Russian).

9. Dezhina, I. (2011). Vliyanie globalizatsii na razvitie rossiiskoi nauki [The Influence of Globalization on the Development of Russian Science]. In: Rossiya v politsentrichnom mire [Russia in Polycentric World]. Moscow: Ves' Mir, pp. 29-38.

10. Dezhina, I. \& Simachev, Yu. (2013). Svyazannye granty dlya stimulirovaniya partnerstva kompanii i universitetov $\mathrm{v}$ innovatsionnoi sfere: startovye effekty primeneniya v Rossii [Matching Grants for Stimulating Partnerships between Companies and Universities in Innovation Area: Initial Effects in Russia ]. Journal of New Economic Association, no 3, pp. 99-122.

11. Dezhina, I. (2014a). Technology Platforms in Russia: a Catalyst for Connecting Government, Science, and Business? Triple Helix Journal (open access journal), vol. 1, no 6. Available at: doi: 10.1186/s40604-014-0006-x (accessed: 21 Jun, 2017).

12. Dezhina, I. (2014b). Mezhsektoral'naya mobil'nost' nauchnykh kadrov - mirovye tendentsii i osobennosti Rossii [Intersectoral Mobility of Scientific Researchers World Trends and the Peculiarities of Russia]. Public Administration Issues, no 3, pp. $30-48$.

13. Dezhina, I. (ed.) (2015). Razvitie sotrudnichestva s russkoyazychnoi nauchnoi diasporoi: opyt, problemy perspektivy [Development of Collaboration with RussianSpeaking Research Diaspora: Experience, Problems, Prospects]. Report no 23/2015. Moscow: RCID (in Russian).

14. Dezhina, I. (2017). Sostoyanie nauki i innovatsii [State of Science and Innovations]. In: Rossiiskaya ekonomika v 2016 godu. Tendentsii i perspektivy [Russian Economy in 2016. Trends and Prospects]. Moscow: Gaidar Institute Publishing, pp. 466-467.

15. Dezhina, I., Medovnikov, D. \& Rozmirovich, S. (2017). Otsenki sprosa rossiiskogo srednego tekhnologicheskogo biznesa na sotrudnichestvo s vuzami [Evaluating the Demand of Russian Medium-Size Technological Companies on Cooperation with Higher Educational Institutes]. Journal of New Economic Association (unpublished). 
16. Dushina, S., Nikolaenko, G. \& Evsikova, E. (2016). Vremya rabotat' v Rossii? Molodye uchenye v usloviyakh institutsional'nykh izmenenii [Time to Work in Russia? Young Scientists in the Conditions of Institutional Changes]. Sociology of Science and Technology, vol. 7, no 3, pp. 29-50.

17. Flanagan, K., Uyarra, E. \& Laranja, M. (2010). The 'Policy Mix' for Innovation: Rethinking Innovation Policy in a Multi-Level, Multi-Actor Context. Manchester Business School Working Paper No 599. Available at: https://mpra.ub.uni-muenchen. de/23567/1/Policy_Mix_For_Innovation.pdf (accessed: 21 May 2017).

18. Flanagan, K., Uyarra, E. \& Laranja, M. (2011). Reconceptualising the 'Policy Mix' for Innovation. Research policy, vol. 40, pp. 702-713.

19. Freeman, C. (1995). The 'National System of Innovation' in Historical Perspective. Cambridge Journal of Economics, vol. 19, pp. 5-24.

20. Gerden, E. (2015). Russia Faces International Scientific Blockage. Chemistry World. Available at: https://www.chemistryworld.com/news/russia-faces-international-scientific-blockade/8846.article (accessed: May 21 2017).

21. Gershman, M., Zinina, T., Romanov, M. et al. (2015) Programmy innovatsionnogo razvitiya kompanii s gosudarstvennym uchastiem: promezhutochnye itogi i prioritety [Programs of Innovative Development of State Companies: Intermediate Results and Priorities]. Moscow: HSE.

22. Gnidchenko, A., Mogilat, A., Mikheeva, O. \& Salnikov V. (2016). Foreign Technology Transfer: An Evaluation of the Russian Economy Dependence on High Tech Imports. Foresight and STI Governance, vol. 10, no 1, pp. 62-66.

23. Gokhberg, L, Zaichenko, S., Kitova, G. \& Kuznetsova, T. (2011). Nauchnaya politika: global'nyi kontekst i rossiiskaya praktika [Science Policy: Global Context and Russian Practice]. Moscow: HSE.

24. HSE (2016). Indikatory nauki: 2016 (statisticheskii sbornik) [Science Indicators: 2016 (Data Book)]. Moscow: HSE.

25. HSE (2017a). Indikatory innovatsionnoi deyatel'nosti: 2017 (statisticheskii sbornik) [Indicators of Innovative Activity: 2017 (Data Book)]. Moscow: HSE.

26. HSE (2017b). Indikatory nauki: 2017 (statisticheskii sbornik) [Science Indicators: 2017 (Data Book)]. Moscow: HSE.

27. HSE, PWC, Fund for Industrial Development (2016). Ot “Tekhuspekha" $k$ natsional'nym chempionam. Natsional'nyi reiting rossiskikh bystrorastushchikh tekhnologicheskikh kompanii “Tekhuspekh-2016” [From “Techuspekh” to National Champions. National Rating of Russian fast-Growing Technological Companies “Techuspekh-2016”]. Moscow: HSE, PWC, Fund for Industrial Development (in Russian).

28. Guston, D.H. (1996). Principal-Agent Theory and the Structure of Science Policy. Science and Public Policy, vol. 23, no 4, pp. 229-240.

29. Elsevier (2011). International Comparative Performance of the UK Research Base 2011. A report prepared for the Department of Business, Innovation and Skills. 
30. Ivanova, N., Egorov, I. \& Radosevic, S. (Eds.) (2008). Analiz innovatsionnoi politiki Rossii i Ukrainy po metodologii Evropeiskogo Soobshchestva [Analysis of Innovation Policy in Russia and Ukraine with Respect to the EU Methodology]. Moscow: IMEMO RAS. (in Russian).

31. Ivanova, N. (Ed.) (2012) Nauka i innovatsii: vybor prioritetov [Science and Innovations: Choice of Priorities]. Moscow: IMEMO RAS (in Russian).

32. Kuhlmann, S. (2003). Evaluation of Research and Innovation Policies: A Discussion of Trends with Examples from Germany. International Journal of Technology Management, vol. 26, pp. 131-149.

33. Lundvall, B-A. (Ed.) (1992). National Systems of Innovation. Towards a Theory of Innovation and Interactive Learning. London: ANTHEM PRESS.

34. Martin, B (2016). R\&D Policy Instruments - A Critical Review of what We do and don't Know. Industry and Innovation, vol. 23, no 2, pp. 157-176. Available at: doi: 10.1080/13662716.2016.1146125 (accessed: 21 Jun, 2018).

35. Medovnikov, D. (2017). Innovatsionnaya Rossiya sosredotachivaetsya [Innovative Russia is Concentrating] Stimмул. Available at: https://stimul.online/articles/interview/innovatsionnaya-rossiya-sosredotachivaetsya-2/ (accessed: 21 May, 2017).

36. Van der Meulen, B. (1998). Science Policies as Principal-Agent Games: Institutionalization and Path Dependency in the Relation between Government and Science. Research Policy, vol. 27, no 4, pp. 397-414.

37. Muhametshina, E. (2015). Iz Rossii ushla pervaya iz organizatsii, vnesennykh v "patrioticheskii stop-list” [First Organization on the 'Patriotic Stop List' to Leave Russia]. Vedomosti. Available at: https://www.vedomosti.ru/politics/articles/2015/07/23/601800-izrossii-ushla-pervaya-iz-organizatsii-vnesennih-v-patrioticheskii-stop-list (accessed: 21 May, 2017).

38. Nelson, R. (Ed.) (1993). National Innovation Systems. A Comparative Analysis. Oxford: Oxford Univ. Press.

39. OECD (2016). Science, Technology, and Industry Outlook. Paris: OECD.

40. Peremitin, G. (2015). Putin podpisal zakon o nezhelatel'nykh inostrannykh organizatsiyakh [Putin Signs the Undesirable Organizations Law]. RBK. Available at: http://www.rbc.ru/politics/23/05/2015/55609f719a794774b30bd2a7 (accessed: 21 May, 2017).

41. Russkogovoryashchie uchenye SShA, Evropy i Azii planiruyut sozdat' v TPU shest' laboratorii (2015) [Russian-Speaking Researchers in the US, Europe and Asia Plan to Set Up Six Labs in Tomsk Polytechnic University]. Sluzhba Novostey Tomsk Politechnical University. Available at: http://news.tpu.ru/news/2015/05/05/23341 / (Accessed 21 May 2017).

42. Saprykina, D. (2017) Bol'shie ozhidaniya: chego molodye uchenye zhdut ot svoei budushchei kar'ery [Big Expectations: What Do Young Scientists Expect from Their Future Career]. Indicator. Available at: https://indicator.ru/article/2017/02/07/ bolshie-nadezhdy/ (accessed: 21 May, 2017). 
43. Skolnikoff, E. (1993). The Elusive Transformation: Science, Technology, and the Evolution of International Politics. Princeton, NJ: Princeton University Press.

44. TSISN (1997). Nauka Rossii v tsifrakh-1997 (Statisticheskiy sbornik) [Science in Russia in figures-1997]. Moscow: TSISN.

45. Vishnevetskaya, Yu. (2016). "Primanka mozgov": mozhno li vernut' uekhavshikh iz Rossii uchenykh? ['Attracting Brain': Is it Possible to Return Back Researchers Who Left Russia?]. Inosmi.Ru. Available at: http://inosmi.ru/science/20160630/237032504. html (accessed: 21 May, 2017).

46. Weiss, C. (2005). Science, Technology and International Relations. Technology in Society, vol. 27, no 3, pp. 295-313.

47. Witt, U. (2003). Economic Policy Making in Evolutionary Perspective. Journal of Evolutionary Economics, vol. 13, no 2, pp. 77-94.

48. World Economic Forum Global Competitiveness Report 2015-2016. Available at: http://www3.weforum.org/docs/gcr/2015-2016/RUS.pdf (accessed: 21 May, 2017).

49. World Economic Forum Global Competitiveness Report 2016-2017. Available at: http:// reports.weforum.org/global-competitiveness-index/country-profiles/\#economy=RUS (accessed: 21 May, 2017).

50. Zudin, N., Kuzyk, M. \& Simachev Yu. (2017). Nauchno-proizvodstvennaya kooperatsiya v Rossii: sovremennoe sostoyanie, problemy, vliyanie gosudarstvennoi podderzhki [Scientific-Industrial Cooperation in Russia: Current Conditions, Problems, Influence of Government Support]. In: Rossiiskaya ekonomika v 2016 godu. Tendentsii i perspektivy. [Russian Economy in 2016. Trends and Prospects]. Moscow: Gaidar Institute Publishing, pp. 430-459. 